ИЗВЕСТИЯ АКАДЕМИИ НАУК ЭСТОНСКОЯ ССР. ТОМ 31

ГЕОЛОГИЯ. 1982, № 1

Хельги КЕССЕЛ, Лейли СААРСЕ,

удК $551.794: 551.491 .4(474.2)$

Р. СИНИСАЛУ, К. УТСАЛ

\title{
ГЕОЛОГИЧЕСКОЕ РАЗВИТИЕ ОЗЕРА КАХАЛА
}

Дисэвтрофное оз. Кахала длиной 2400 м, шириной 2000 м и площадью 349,9 га расположено на Северо-Эстонском плато на абсолютной высоте 32,9 м. Озеро мелководное, средняя и максимальная глубины соответственно 1,15 и 2,25 м. Вода гидрокарбонатная, $\mathrm{pH} 9,0$, общая сумма ионов низкая - 51 мг/л (Eesti järved, 1968). Берега озера торфянис тые, за исключением северо-восточной части, где на отмели обнажается морена. Водосборную площадь озера составляют в основном торфянистые, подзолистые и карбонатные почвы. Озеро питается атмосферными осадками, ручьями и родниками (Eesti järved, 1968). Рельеф окрестности озера в общем пологий. На северо-западе озера находится выступ коренных пород Лоо (Тситре), на севере выступ Муукси-Уури и глинтовой уступ. Геологическое развитие и донные отложения оз. Ка. хала рассматривались многими учеными (Кессел, 1968; Thomson, 1929; Määr, 1931; Luha, 1946; Veber, 1970 и др.), однако собранный авторами данной статьи новый фактический материал позволяет более подробно освещать вопросы осадконакопления и геологического развития озера.

\section{Методика исследования}

Условия залегания донных отложений оз. Кахала исследовались бурением со льда Белорусским торфяным буром и буром ТБГ-I, причем пробурено было 96 скважин. Пробы из опорной скважины (№ 96), заложенной в северной части озера, где установлена наибольшая мощность отложений (рис. 1), анализировали палинологически и химиче ски по стандартной методике в лабораториях институтов геологии и химии АН ЭССР. Рентгеноструктурные анализы проведены в Тартуском государственном университете в кабинете минералогии по разра. ботанной К. Утсалом методике (Утсал и др., 1979). Групповой анализ сапропеля проведен на кафедре химии Латвийской сельскохозяйственной академии по разработанной там же методике (Шкеле, Удач, 1978).

\section{Результаты и их обсуждение}

Условия залегания донных отложений. Минеральное дно озера с абсолютными отметками $25,5-26,0$ м в наиболее глубоких участках озерной впадины покрыто алевритом, а в береговой зоне песком (рис. 1). В опорном разрезе под алевритом на глубине 7,6 м залегает светлосерый ленточнослоистый алевритовый пелит, имеющий по данным спорово-пыльцевого анализа позднедриасовый возраст. Надстилающая толща синевато-серого алеврита мощностью около 1 м была пройдена несколькими скважинами. Нижняя часть ее (интервал $7,25-7,60$ м) 


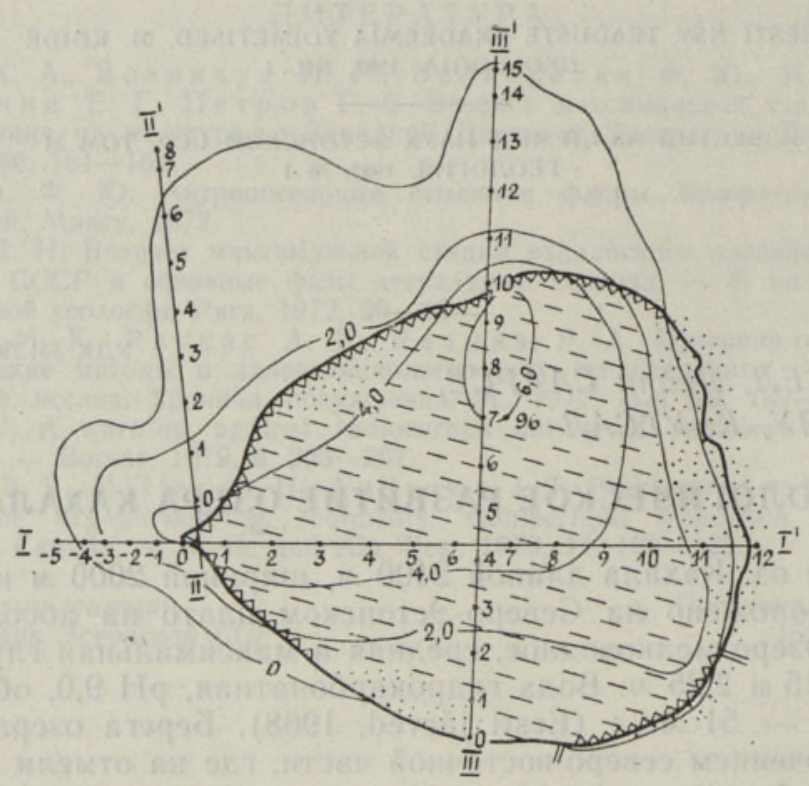

Рис. 1. Минеральное дно озера с расположением геологических разрезов и мощностей сапропеля.

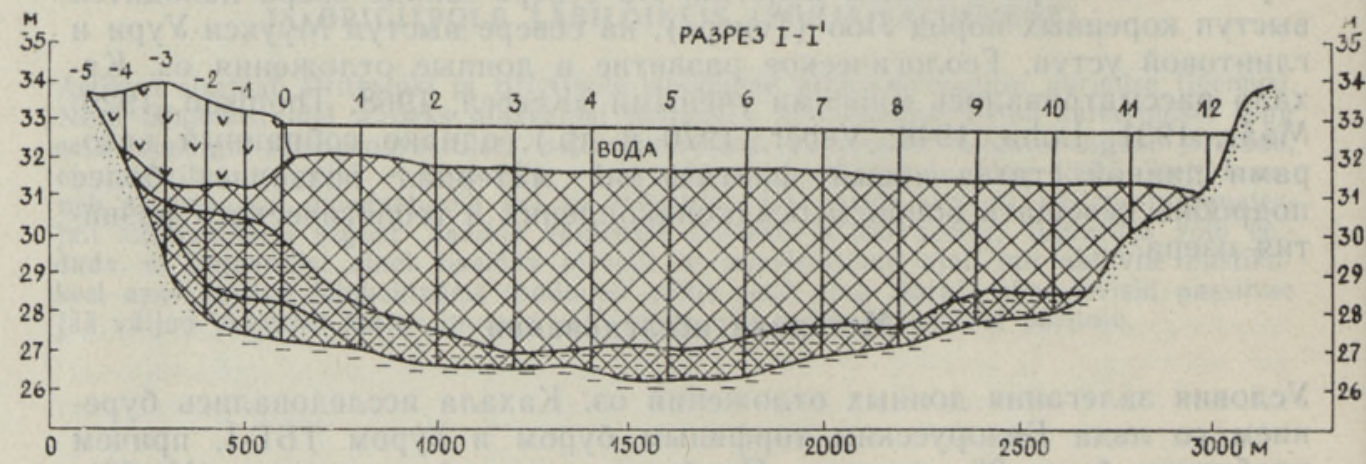

Рис. 2. Разрез донных отложений по линии $\mathrm{I}-\mathrm{I}^{\prime}$ (см. рис. 1). Условные обозначения см. рис. 3 .

образовалась в первую половину пребореала, верхняя (интервал: $6,70-7,25$ м), содержащая рассеянное органическое вещество, придающее отложению своеобразный темно-зеленый цвет, - во вторую половину пребореала и зоны березы.

Минеральные образования покрыты сапропелевыми отложениями, которые отсутствуют лишь на узкой восточной береговой полосе (рис. 1), причем мощность сапропелевой толщи доходит до 6,5 м (сред. няя 3,5 м) (рис. $2,3,4)$. Так как площадь оз. Кахала в раннем голоцене была значительно больше современной, сапропели были обнаружены и на территории в 238 га вне озера (рис. 1).

По составу, консистенции, уплотненности и окраске снизу вверх выделены следующие разновидности сапропелей: 1) серовато-коричневый грубодетритовый плотный сапропель (интервал $6,70-5,40, м$ ), которому соответствуют палинозоны сосны, лещины и вяза (рис. 5); 2) коричневый студенистый чистый сапропель (интервал $5,40-3,10$ м), характеризующийся палинозонами липы, дуба, нижней ели, березы и ольхи; 3) сероватый от светло- до средне-коричневого малоуплотнен- 


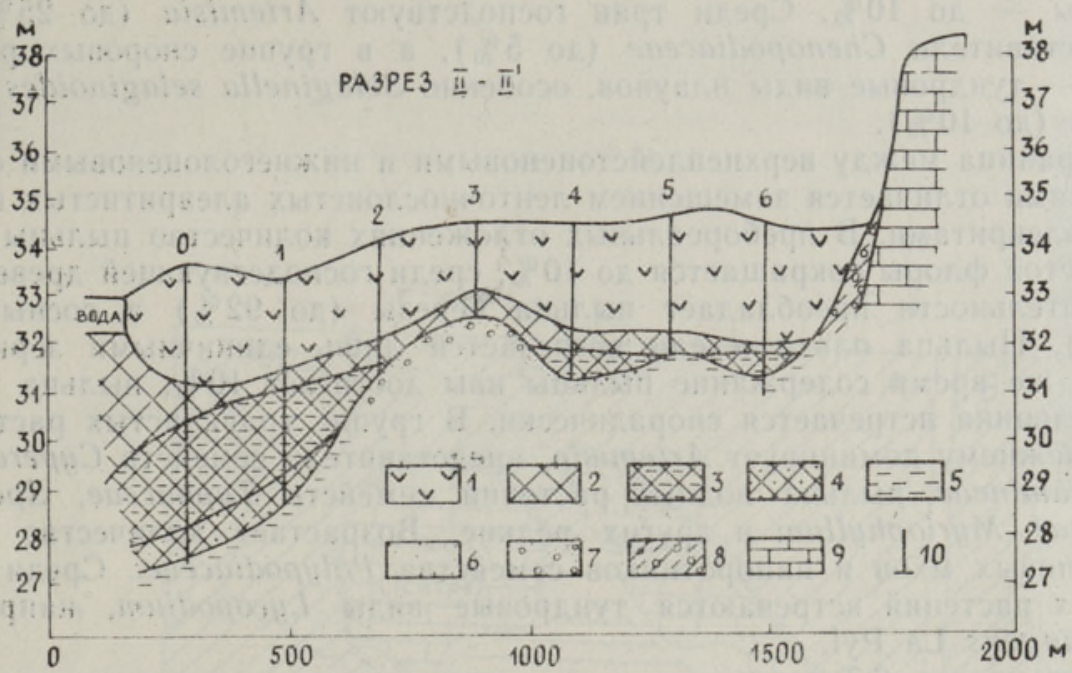

Рнс. 3. Разрез донных отложений по линни II- $\mathrm{II}^{\prime}$ (см. рис. 1). Условные ообозначения: 1 - торф, 2 - слабостуденистый и студенистый сапропель, 3 - алевритистый сапропель, 4 - песчанистый сапропель, 5 алеврит, 6 - песок, 7 - гравистый песок с галькой, 8 - морена, $9-$ известняк, 10 - буровые скважины.

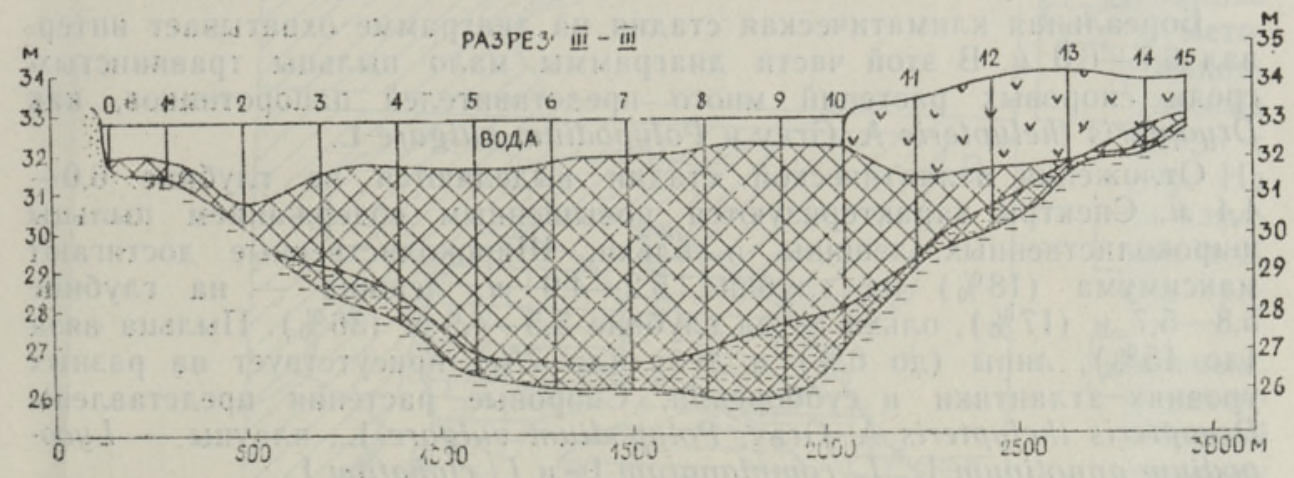

Рис. 4. Разрез донных отложений по линии чения см. рис. 3 .

ный слабостуденистый грубодетритовый сапропель $(3,10-1,1$ м), совпадающй с палинцозонами верхней ели, сосны и березы (рис. 5). При анализе распространения названных разновидностей сапропеля по всей озерной котловине можно отметить широкий размах слабостуденистого и студенистого сапропеля.

Палинологическая характеристика. На спорово-пыльцевой диаграмме опорного разреза (скв. № 96) выделены следующие палинозоны голоцена. В самой нижней палинологически изученной части разреза (интервал 7,6-8,0 м) в основном наблюдается пыльца древесных пород с явным преобладанием пыльцы березы (около 40-70\%). Относительно велико содержание пыльцы Betula nana L. и B. humilis Schrank (до $30 \%$ ). Часто, хотя и в незначительных количествах (до $5 \%$ ), встречается пыльца ивы. Содержание переотложенной пыльцы ольхи достигает $26 \%$. Эту часть разреза можно отнести к верхнедриасовой зоне, что подтверждается также видовым составом и количеством пыльцы травяннстой флоры: пыльца травянистых растений составляет $10-27$, 
споры - до 10\%. Среди трав господествуют Artemisia (до 25\%) и представители Chenopodiaceae (до $5 \%$ ), а в группе споровых растений - тундровые виды плаунов, особенно Selaginella selaginoides (L.) Link. (до 10\%).

Граница между верхнеплейстоценовыми и нижнеголоценовыми отложениями отличается замещением ленточнослоистых алевритистых пелитов алевритами. В пребореалыных отложениях количество пыльцы травянистой флоры сокращается до $10 \%$, среди господствующей древесной растительности преобладает пыльца березы (до $92 \%$ ) и сосны (до $35 \%$ ). Пыльца ольхи и ели встречается лишь единичными зернами. В то же время содержание пыльцы ивы достигает $10 \%$, пыльца можжевельника встречается спорадически. В группе травянистых растений по-прежнему доминирует Artemisia, представители семейств Cyperaceae и Gramineae, пыльца водных растений семейств Typhaceae, Sparga. niaceae, Myriophyllum и других редкие. Возрастает количество спор сфагновых мхов и папоротников семейства Polypodiaceae. Среди споровых растений встречаются тундровые виды Lycopodium, например L. pungens La Pyl.

На уровне 6,7 м значительное уменьшение содержания пыльцы березы отмечает границу между пребореальной и бореальной и соот. ветственно между иольдиевой и анциловой стадиями. Примерно на этом уровне проходят эмпирические границы пыльцы ольхи и вяза и начинается господство пыльцы сосны. Содержание пыльцы березы составляет в среднем $40-50 \%$, пыльцы лещины - 5\%.

Бореальная климатическая стадия на диаграмме охватывает интервал $6,7-6,0$ м. В этой части диаграммы мало пыльцы травянистых, среди споровых растений много представителей папоротников, кав Dryopteris thelypteris A. Gray и Polypodium vulgare L.

Отложения атлантической стадии выделяются на глубине 6,04,4 м. Спектры характеризуются повышенным содержанием пыльцы широколиственных, лещины и ольхи. Широколиственные достигают максимума $(18 \%)$ на глубине $5,2-4,9$, лещина - на глубине $5,8-5,7 \mu(17 \%)$, ольха - на глубине $5,5-4,9$ м $(36 \%)$. Пыльца вяза (до $15 \%$ ), липы (до $6 \%$ ) и дуба (до $7 \%$ ) присутствует на разных уровнях атлантики и суббореала. Споровые растения представлены Dryopteris thelypteris A. Gray, Polypodium vulgare L., плауны - Lycopodium annotinum L., L. complanatum L. и L. clavatum L.

Атлантические и суббореальные сапропели оз. Кахала содержат в большом количестве пыльцу таких водных растений, как Potamogeton, Sparganum, Myilophyllum, Typha latifolia L., Menyanthes trifoliata L., Nymphaceae и др. Содержание некоторых из них доходит послойно до $5 \%$, особенно обильно встречается пыльца Myriophyllum и Potamogeton. В составе трудноопределяемой пыльцы водных растений часто встречается пыльца растений семейств Alismataceae и Hydrochaidaceae.

По сравнению со спорово-пыльцевыми спектрами сапропеля атлантической стадии в спектрах сапропеля суббореальной стадии (на глу. бине $4,4-3,8$ м) наблюдается меньше пыльцы широколиственных пород, кроме пыльцы дуба и ольхи. На фоне увеличения содержания пыльцы сосны и березы бросается в глаза сильное уменьшение содержания пыльцы лещины. В этой части диаграммы пыльца граба состав. ляет до $2 \%$. Спорово-пыльцевые спектры субатлантического сапропеля (интервал 3,8-1,1 м) по составу древесных пород близки спектрам сапропеля суббореальной стадии. Заметно увеличивается содержание пыльцы сосны (до 62\%) и березы (до $30 \%$ ), обнаруживается верхний максимум ели (до $29 \%$ ).

На основе полученных нами данных и стратиграфической схемы 


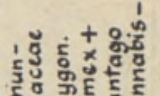

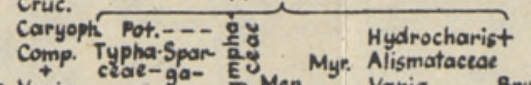

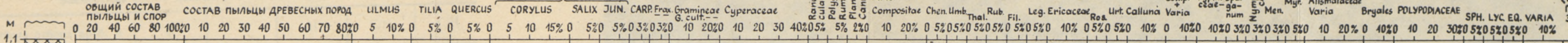

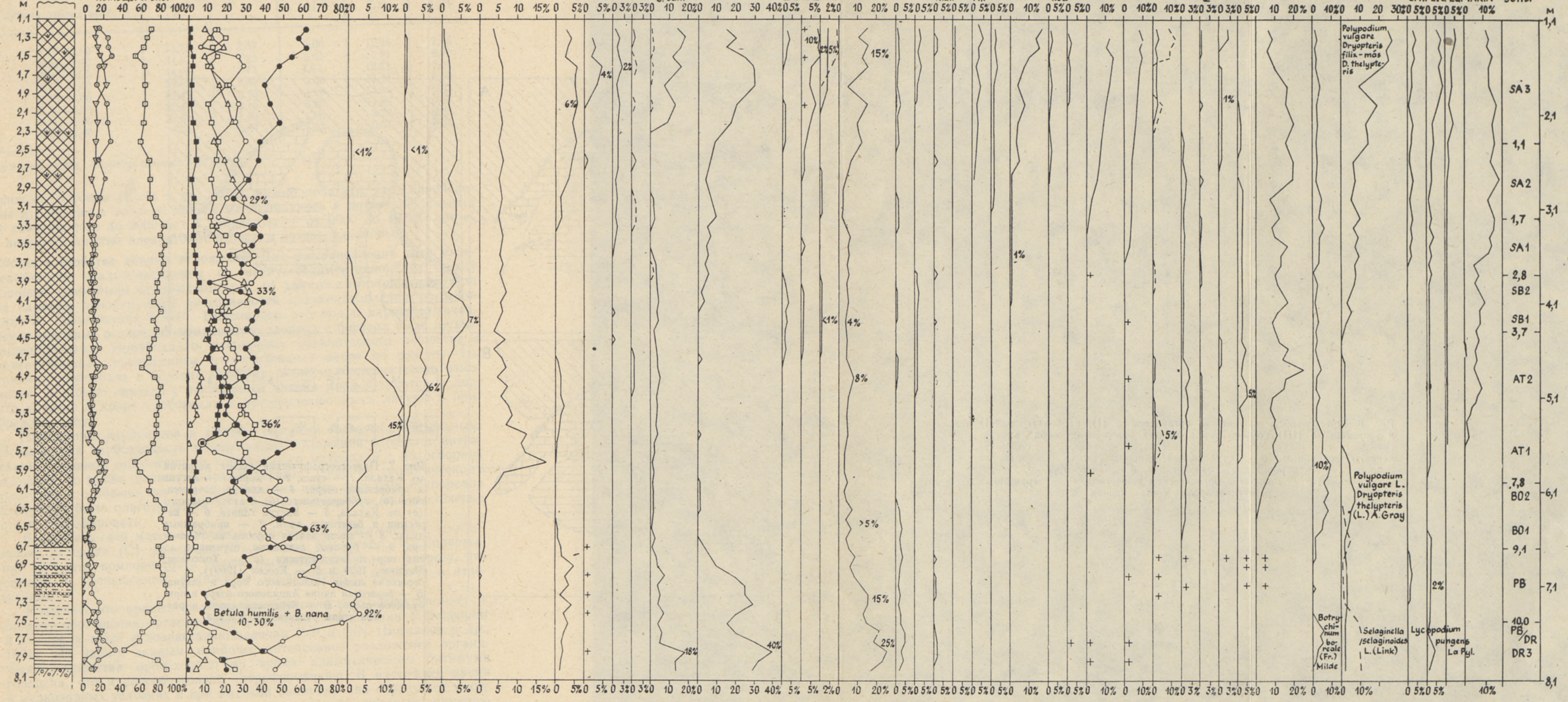

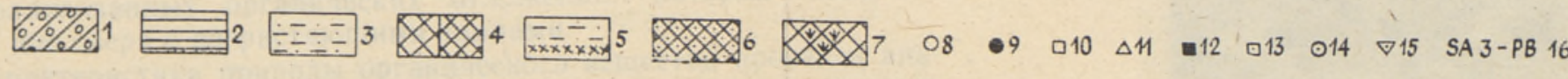

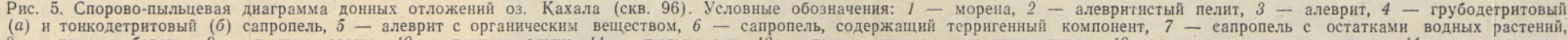
$8-$ пыльца березы, 9 - пыльца сосны, $10-$ пыльца ольхи, 11 - пыльца ели, $12-$ пылыца широколиственных пород, $13-$ пыльца древесных пород, $14-$ пыльца тра- 
CKB. $9 \%$ I , II III

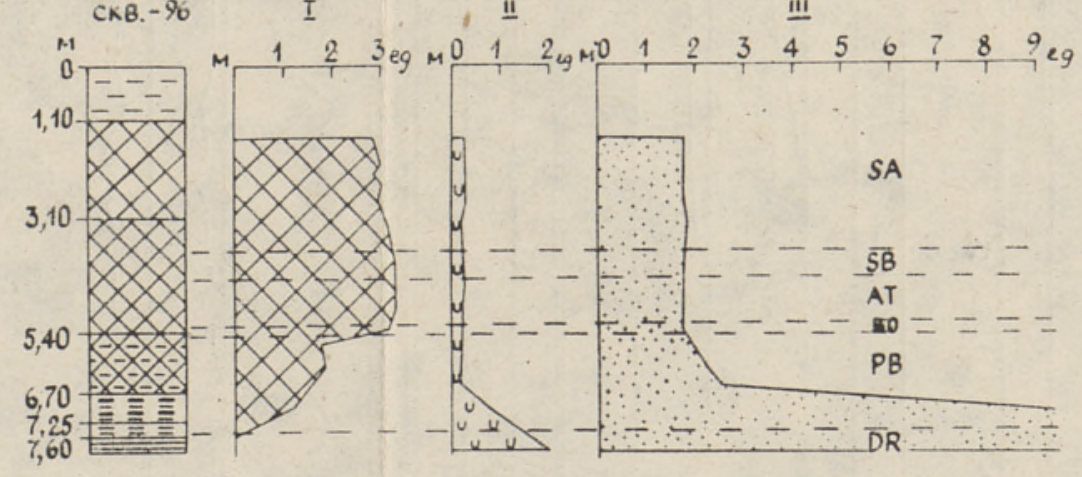

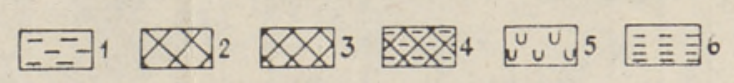

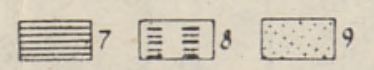

Рнс. 6. Интенсивность накопления органического (I), карбонатного (II) и терригенного (II)) компонентов в донных отложениях озера (в отно денистый сапропель, $3-$ студенисый сапропель, $4-$ алевритисты тистый пелит, 8 - алеврит с органическим веществом, 9 - терригенная и рентгеноаморфная составляющая.
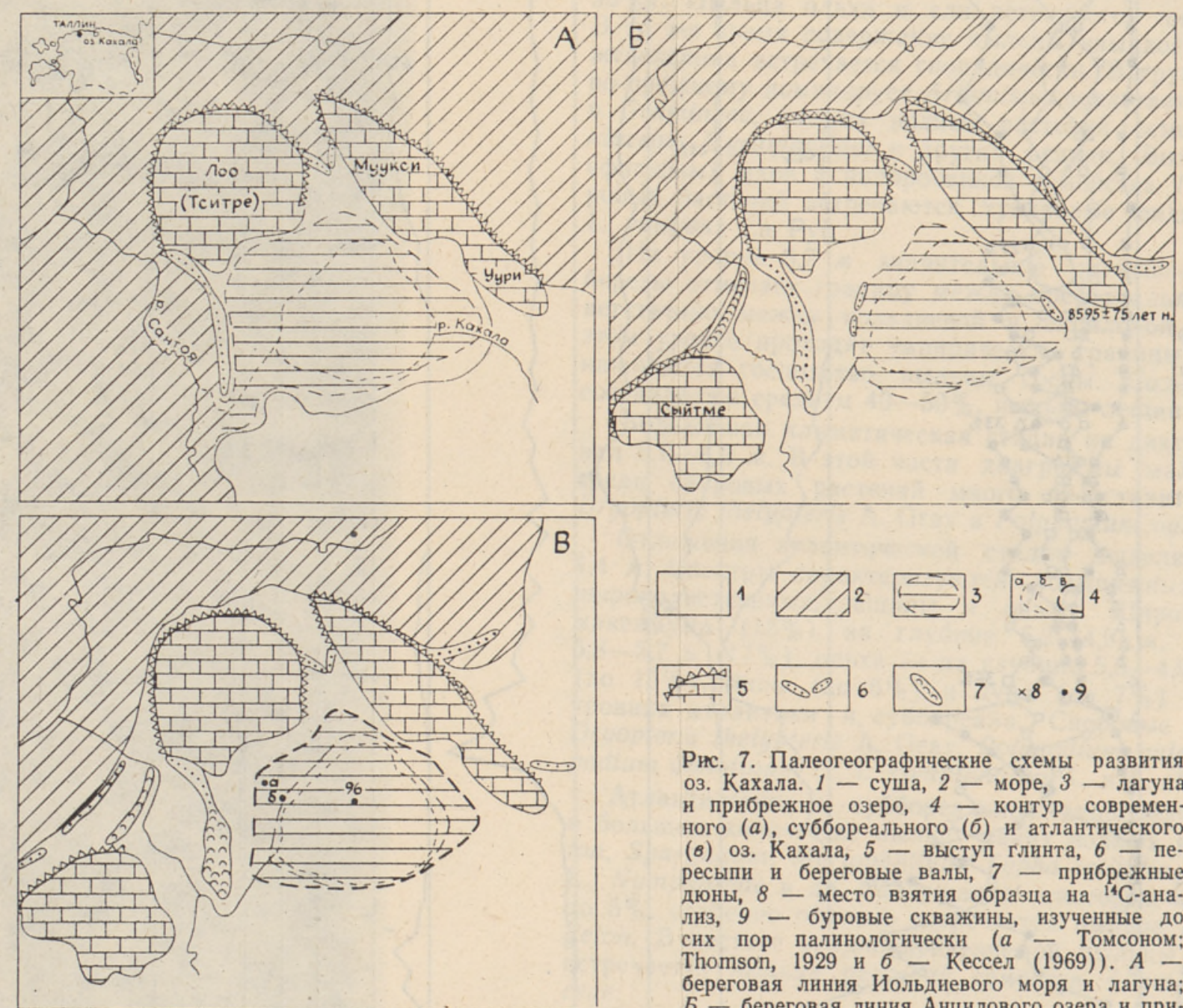

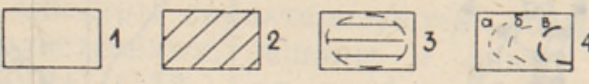

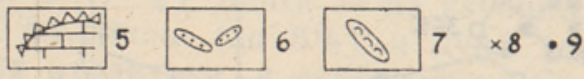

Рис. 7. Палеогеографические схемы развития оз. Кахала. 1 - суша, 2 - море, 3 - лагун (6) (в) оз. Кахала, 5 - выступ глинта, 6 - пересыпи и береговые валы, 7 - прнбежны дюны, 8 - место взятия образца на " ${ }^{4} \mathrm{C}$-ана(19x Thomson, 1929 н 6 - Кессел (1969)). A береговая линия Иольдиевого моря и лагуна; $D-$ береговая линия Анщилового озера н прн-
брежное озеро; $B$ - береговые линии в раз ные этапы развитня оз. Кахала. 
Элементный состав донных отложений озера Кахала, \%

\begin{tabular}{c|c|c|c|c|c}
\hline Глубина отбора проб, $\mu$ & $\mathrm{C}$ & $\mathrm{N}$ & $\mathrm{H}$ & $\mathrm{C} / \mathrm{N}$ & $\mathrm{C} / \mathrm{H}$ \\
\hline & & & & & \\
\hline $2,75-2,00$ & 35,75 & 2,87 & 5,00 & 12,45 & 7,15 \\
$2,25-2,50$ & 34,57 & 2,83 & 5,01 & 12,21 & 6,90 \\
$3,00-3,25$ & 34,90 & 2,73 & 4,94 & 12,78 & 7,06 \\
$3,75-4,00$ & 32,98 & 2,46 & 5,00 & 13,41 & 6,60 \\
$4,75-5,00$ & 32,47 & 2,43 & 4,70 & 13,36 & 6,91 \\
$5,40-5,50$ & 25,47 & 2,15 & 3,82 & 11,85 & 6,67 \\
$6,00-6,25$ & 23,62 & 1,62 & 1,96 & 3,70 & 6,38 \\
$6,75-7,00$ & 8,04 & 0,84 & 1,33 & 9,57 & 6,05
\end{tabular}

Пр и меч ан и е. Анализы провела Р. Соосалу.

голоцена Эстонии (Каяк и др., 1976) можно полагать, что сапропеле. вые отложения в разрезе Кахала накапливались в интервале времени от современного до 9000 лет н., алевриты - от 9000 до 10000 лет н. и ленточнослоистые алевритовые пелиты в позднеледниковье.

Состав и свойства донных отложений. Для восстановления хода и интенсивности осадконакопления по всему седиментационному циклу голоцена нами были пересчитаны (рис. 6) данные химического анализа на единицы относительной интенсивности осадконакопления по методике А. Гарункштиса (1970). Выяснилось, что ход и характер накопления основных осадочных компонентов начиная с бореала были весьма выдержанными. Преобладало накопление органического вещества с незначительным уменьшением его содержания вверх по разрезу. На границе пребореала и бореала характер осадконакопления резко изме. нился. Это было связано с понижением уровня моря и грунтовых вод, что привело в конце пребореала к превращению здесь лагуны в прибрежное озеро.

Накопление карбонатов в течение голоцена было незначительным. Повышенная карбонатность минерогенных отложений отражает интенсивный привнос аллотигенного карбонатного материала с водосборной площади, а также размыв озерных берегов. Судя по геологическому развитию и особенностям осадконакопления озеро во время пребореала и бореала было олиготрофным, а начиная с атлантики оно постепенно стало эвтрофировать.

В органической массе сапропеля определены содержание и соотіошения углерода (C), водорода $(\mathrm{H})$ и азота (N) (табл. 1). Содержание всех этих компонентов в общем уменьшается вниз по разрезу, что связано с уменьшением количества органического вещества в отложениях.

Известно, что процесс разложения органического вещества идет в сторону обогащения органическим углеродом в сравнении с фосфором и азотом, и ведет к возрастанию величин $\mathrm{C} / \mathrm{P}$ и $\mathrm{C} / \mathrm{N}$ (Богданов и др., 1971). По нашим данным, наиболее интенсивное разложение органического вещества происходило во время климатического оптимума голоцена, что и способствовало эвтрофированию. В настоящее время в мелководных условиях и при высокой биопродукции образуется много маломинерализованных органических отложений, которые накапливаются на дне озера с возрастающими темпами.

Для характеристики природы органического вещества проведен анализ его группового состава. Выделяются: а) извлекаемые из сапропеля органическими растворителями битумы; б) растворимые и легко гидролизуемые целлюлозы, гемицеллюлоза и сахара; в) извлекаемые из 
Содержание карбонатов и органического -вещества.в донных отложениях оз. Кахала (скв. 96), \%

\begin{tabular}{|c|c|c|c|c|}
\hline$\underset{M}{\text { Глубина отбора проб, }}$ & $\mathrm{CaO}$ & $\mathrm{MgO}$ & $\begin{array}{c}\text { Карбонат- } \\
\text { ность по } \\
\mathrm{CO}_{2}\end{array}$ & $\begin{array}{l}\text { Органиче- } \\
\text { ское веще- } \\
\text { ство по } \\
\text { Сорг. }\end{array}$ \\
\hline $\begin{array}{l}1,50-1,75 \\
1,75-2,00 \\
2,00-2,25 \\
2,25-2,50 \\
2,50-2,75 \\
3,00-3,25 \\
3,75-4,00 \\
4,25-4,50 \\
4,75-5,00 \\
5,25-5,40 \\
5,50-5,75 \\
6,00-6,25 \\
6,25-6,50 \\
6,75-7,00 \\
7,60-7,90\end{array}$ & $\begin{array}{l}0,64 \\
0,62 \\
1,55 \\
\overline{1,23} \\
1,28 \\
0,64 \\
0,64 \\
\overline{1,38} \\
1,27 \\
0,64 \\
- \\
1,63 \\
3,65\end{array}$ & $\begin{array}{l}1,38 \\
0,98 \\
\overline{1,03} \\
\overline{0} \\
0,92 \\
0,92 \\
1,28 \\
1,42 \\
0,49 \\
0,28 \\
0,92 \\
1,63 \\
1,57 \\
2,05\end{array}$ & $\begin{array}{r}5,42 \\
4,13 \\
5,49 \\
5,11 \\
4,81 \\
3,06 \\
3,77 \\
5,20 \\
4,40^{2} \\
4,09 \\
4,99 \\
3,31 \\
4,47 \\
7,74 \\
12,28\end{array}$ & $\begin{array}{c}58,4 \\
60,5 \\
69,1 \\
59,9 \\
59,9 \\
61,1 \\
62,7 \\
62,0 \\
61,9 \\
61,5 \\
45,8 \\
43,9 \\
37,3 \\
12,3 \\
0\end{array}$ \\
\hline
\end{tabular}

Пр и ме ч ан ие. Анализы провела Ы. Роос.

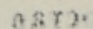

сапропеля раствором щелочи гуминовые и фульвовые кислоты и г) негидролизуемые вещества (лигнин).

Битуминозность (содержание асфальтенов, восков, парафинов, масел) изученных сапропелей незначительная. В валовой пробе (раз. рез III, скв. 9, зольность $41,7 \%$ ) в органической массе содержится $9,5 \%$ битумов. Преобладают легкогидролизуемые и негидролизуемые вещества - 19,2 и 19,6\% соответственно. Содержание гуминовых кислот низкое - 13,0\%. Так как они получаются в процессе преобразования органического вещества живого и растительного происхождения (живые организмы не содержат гуминовых кислот), то процесс гумификации отражает степень минерализации органического́ вещества и в данном случае свидетельствует о неблагоприятных условиях минерализации.

Судя по данным рентгеноструктурного и химического анализов, карбонатная часть донных отложений представлена в основном доломитом. Малая карбонатность отложений (табл. 2), отношение кальцита к доломиту и приуроченность карбонатных минералов к терригенным отложениям показывают, что в оз. Кахала пе было благоприятных условий для аутигенного карбонатообразования.

Терригенная часть донных отложений по данным дифрактограмм и химических анализов состоит в основном из кварца и аморфного кремнезема (содержание $\mathrm{SiO}_{2}$ от 10 до $42 \%$ в студенистом и слабостуденистом сапропеле и от 31 до $65 \%$ в алевритистом сапропеле). Полуторных окислов содержится $2,1-8,0$ и 2,3-6,9\% соответственно.

Основные палеогеографические выводы. Оз. Кахала располюжено на поднимающемся побережье Низинной Эстонии и отделилось от Иольдиевого моря в остаточное прибрежное озеро во время пребореальной климатической стадии.

В начале пребореала при стабилизации уровня Иольдиевого моря около 10000 лет н. (рис. 7А) здесь пересыпями между поселками Лоо, Кахала и Лийва и между выступами коренных пород Лоо и Муукси отделилась лагуна. Соответствующая береговая линия и уровень воды в лагуне находились на абсолютных высотах, $34-35$ м. Во второй, поло- 
вине пребореала Иольдиевое море регрессировало и в озерной котловине формировалось самостоятельное прибрежное озеро. Перед трансгрессией Анцилового озера около 9000 лет н. уровень воды в изученном озере был низким (на абсолютной высоте 28 м), о чем свидетельствует возраст погребенного торфа на восточном берегу озера $(8595 \pm 75$ лет, ТА-59; Ильвес и др., 1974). Во время трансгрессии Анцилового озера береговая линия находилась на абсолютной высоте 30-32 м (рис. 7Б). Тогда и сформировались погребенные под торфом и сапропелем береговые валы на абсолютной высоте около 31 м (рис. 3). Оз. Кахала существовало в это время самостоятельно, так как береговая линия Анцилового озера проходила северо-западнее между поселками Сыйтме, Тситре и Муукси. В связи с увлажнением климата в атлантической климатической стадии во время распространения литоринового моря контуры озера были значительно больше современных (рис. 7B). В суббореале (Кессел, 1968) началось интенсивное зарастание озера, что продолжается и в настоящее время. При этом в субатлантике объем озера значительно уменьшился за счет интенсивного накопления донных отложений.

\section{Л И ТЕ РА Т У Р А}

Богданов Ю. А., Лисицын А. П., Романкевич Е. А. Органическое вещество взвесей и донных осадков морей и океанов. - В кн.: Органическое вещество современных и ископаемых осадков. М., 1971, 35-103.

Г а р у нкш т и с А. Некоторые черты седиментационных процессов в озерах Литвы. В кн.: История озер. Тр. Всесоюз. симпозиума. II. Вильнюс, 1970, 497-511.

Ильвес Э., Лий в а А., Пуннин Г Я.-М. Радиоуглеродный метод и его применение в четвертичной геологии и археологии Эстонии. Таллин, 1974.

Kаяк K., Кессел X., Л ий в ранд $Э$. и др. Местная рабочая стратиграфическая схема четвертичных отложений Эстонии. - В кн.: Стратиграфия четвертичных отложений Прибалтики. Вильнюс, 1976, 4-52.

Кессел Х. Формирование озер на поднимающемся побережье Эстонии. - Изв. АН ЭССР. Хим.Геол., $1968,17,59-66$.

Шкеле В., Удач Л. K методике компонентного группового анализа органических веществ сапропеля. - Тр. ЛСХА, 1978, 141, 7-9.

утсал К. Р., Утсал В. И., Лы окене Э. А. Опыт применения рентгеновской дифрактометрии для определения количества аморфной органики и соединений железа в современных озерных и болотных осадках. - В кн.: Рентгенография минерального сырья и кристаллохимия минералов. М., 1979, 56-76.

Eesti järved. Tln., 1968.

Luha, A. Eesti NSV maavarad. Rakendusgeo.oogiline kokkuvõtlik ü'evaade. Tartu, 1946.

M ä ä r, A. Vesikuuse-kärsakas (Litodactylus leucogaster) Kahala järves. - Loodusvaatleja, 1931, 176 .

Thomson, P. W. Die regionale Entwicklungsgeschichte der Wälder Estlands. Acta Univ. Tartu, 1929, A17, 2.

Veber, K. Mõningate Eesti järvede setted. - EMMTUI teadusl. tööde kogumik. 1970, $\mathrm{XX}, 226-237$.

\section{Ннститут геологии}

Академии наук Эстонской ССР

Управление геологии ЭССР

Тартуский государственный университет
Поступила в редакцию 8/VI 1981

Helgi KESSEL, Leili SAARSE, R. SINISALU, K. UTSAL

\section{KAHALA JARRV GEOLOOGILINE ARENG}

Artiklis on käsitłetud Kahala järve nõos kuhjunud setete lasumust, levikut, koostist ja stratigraạfiat ning antud ülẹaade järve arengusț. 


\section{GEOLOGICAL DEVELOPMENT OF LAKE KAHALA}

L. Kahaia is a non-stratified soft-water dyseutrophic lake in the northern part of Estonia at the height of $32.9 \mathrm{~m}$. Lake sediments consist of varying layers of gyttja which overlie silt, stratified clay, till, and limestone bedrock (Figs 1-4). Geological and palyno.ogical studies have revealed that gyttja with the maximum thickness of $6.5 \mathrm{~m}$ represents a sequence starting from the end of the Preboreal up to the present time. Pollen data for the sediments of L. Kahaia are presented in the diagram (Fig. 5), and the content of organic, carbonate and terrigeneous compounds in Fig. 6. The amount of organic carbon, nitrogen and hydrogen is rather similar throughout the gyttja sequence, but it decreases sharply in silts (Table 1).

The history of L. Kahala is complicated. After the Valdaian glaciation this area was submerged in the Baltic Sea. Due to isostatic rebound during the Yoldia Sea, the lake basin turned into a large lagoon with the water level of ca $36-34 \mathrm{~m}$ (Fig. $7 \mathrm{~A}$ ). At the end of the Preboreal this lagoon became an isolated lake. During the Ancylus Lake transgression, the water level decreased to $32-30 \mathrm{~m}$ (Fig. 7Б). The cimatic optimum stage of the middle Holocene is characterized both by warm and humid climate and a high water leve: (Fig. 7B). Later, under the conditions of the dry Subborea: climate, the water level in the basin decreased once again. Nowadays the basin is gradually getting filled with sediments and overgrown by peat. 